Keywords: HTO, deposition velocity, re-emission, Tritium, atmospheric dispersion

Retention: Permanent

\title{
Recommended Tritium Oxide Deposition Velocity for Use in Savannah River Site Safety Analyses
}

C. E. Murphy, P. L. Lee, B. J. Viner and C. H. Hunter

July 31,2012

Savannah River National Laboratory Savannah River Nuclear Solutions, LLC Aiken, SC 29808

Prepared for the U.S. Department of Energy under contract number DE-AC09-08SR22470. 


\section{DISCLAIMER}

This work was prepared under an agreement with and funded by the U.S. Government. Neither the U.S. Government or its employees, nor any of its contractors, subcontractors or their employees, makes any express or implied:

1. warranty or assumes any legal liability for the accuracy, completeness, or for the use or results of such use of any information, product, or process disclosed; or

2. representation that such use or results of such use would not infringe privately owned rights; or

3. endorsement or recommendation of any specifically identified commercial product, process, or service.

Any views and opinions of authors expressed in this work do not necessarily state or reflect those of the United States Government, or its contractors, or subcontractors.

\section{Printed in the United States of America}

Prepared for U.S. Department of Energy 


\section{REVIEWS AND APPROVALS}

\section{AUTHORS:}

C. E. Murphy, Environmental Sciences Group

Date

P. L. Lee, Manager, Applied Computational Engineering \& Sciences

Date

B. J. Viner, Atmospheric Technologies Group

Date

C. H. Hunter, Manager, Atmospheric Technologies Group

Date

TECHNICAL REVIEWER:

G. T. Jannik, Environmental Sciences Group

Date

APPROVALS:

J. J. Mayer, Manager, Environmental Sciences Group

Date 


\section{PREFACE}

In August 2011, the Defense Nuclear Safety Board Staff (DNFSB) stated the "...dry deposition velocity for tritium oxide $(0.5 \mathrm{~cm} / \mathrm{s})$ recommended in the MACCS2 Computer Code Application Guidance for Documented Safety Analysis Final Report and used in consequence analysis for the tritium facilities does not yield the bounding consequence" in a letter to the U.S. Department of Energy (DOE) National Nuclear Security Administration (NNSA) Administrator. The DNFSB Staff Issue Report issued in March 2011 requests technical justification for the appropriateness of the deposition velocity being used for the bounding accident scenario and identifies re-emission of tritium back into the atmosphere, as a phenomenon that must be reflected in the derivation of an appropriate deposition velocity.

In response to the DNFSB inquiry, Tritium Engineering requested that Savannah River National Laboratory (SRNL) determine and document a technical basis for a Savannah River Site (SRS)-specific tritium oxide (HTO) dry deposition velocity value that is appropriate for use in a bounding accident scenario at SRS Nuclear Facilities. In response to this request, environmental transport and dosimetry subject matter experts at SRNL were consulted to address the technical concerns cited by the DNFSB. As part of the investigation, SRNL hired Dr. Charles Murphy; who had retired after 30 years of experience with the behavior of tritium in the environment and has authored several publications on this topic (including site-specific evaluations) and is familiar with the historical worldwide research to assist in this technical evaluation.

This report documents the results of examining the deposition velocity of water to forests, the residence time of HTO in forests, and the relation between deposition velocity and residence time with specific consideration given to the topography and experimental work performed at SRS. A simple mechanistic model is used to obtain plausible deposition velocity and residence time values where experimental data are not available and recommendations are made for practical application in a safety analysis model. 


\section{EXECUTIVE SUMMARY}

The Defense Nuclear Facilities Safety Board (DNFSB) has recently questioned the appropriate value for tritium deposition velocity used in the MELCOR Accident Consequence Code System Ver. 2 (MACCS2) (Chanin and Young 1998) code when estimating bounding dose ( $95^{\text {th }}$ percentile) for safety analysis (DNFSB 2011). The purpose of this paper is to provide appropriate, defensible values of the tritium deposition velocity for use in Savannah River Site (SRS) safety analyses. To accomplish this, consideration must be given to the re-emission of tritium after deposition.

Approximately $85 \%$ of the surface area of the SRS is forested. The majority of the forests are pine plantations, $68 \%$. The remaining forest area is $6 \%$ mixed pine and hardwood and $26 \%$ swamp hardwood. Most of the path from potential release points to the site boundary is through forested land.

A search of published studies indicate daylight, tritiated water (HTO) vapor deposition velocities in forest vegetation can range from 0.07 to $2.8 \mathrm{~cm} / \mathrm{s}$. Analysis of the results of studies done on an SRS pine plantation and climatological data from the SRS meteorological network indicate that the average deposition velocity during daylight periods is around $0.42 \mathrm{~cm} / \mathrm{s}$. The minimum deposition velocity occurs at night and was determined to be about $0.1 \mathrm{~cm} / \mathrm{s}$.

Deposition velocity and residence time (half-life) of HTO in vegetation are related by the leaf area and leaf water volume in the forest. For the characteristics of the pine plantation at SRS the residence time corresponding to the average, daylight deposition velocity is 0.4 hours. The residence time corresponding to the night-time deposition velocity of 0.1 $\mathrm{cm} / \mathrm{s}$ is around 2.5 hours.

A simple dispersion model which accounts for deposition and re-emission of HTO vapor was used to evaluate the impact on exposure to the maximally exposed offsite individual (MOI) at the SRS boundary (Viner 2012). Under conditions that produce the bounding, $95^{\text {th }}$ percentile MOI exposure, (i.e., low wind speed, weak turbulence, night, low deposition velocity), the HTO deposition rate was very low. In addition, the results demonstrate that much of the HTO deposited (50\%) was re-emitted within a two hour period. The effect of deposition on MOI exposure was found to be very small when considering the low initial deposition and subsequent re-emission. The exposure over the two hour period following arrival of the plume was found to be decreased by less than $0.05 \%$. Even under conditions of greater HTO deposition, i.e. deposition velocity 0.5 $\mathrm{cm} / \mathrm{s}$, the combination of deposition and re-emission resulted in an overall exposure reduction of just $0.3 \%$ in the two hour period following arrival of the plume. After a 24 hour period, an MOI would essentially have been exposed to all of the released material.

Because the MACCS2 code only considers deposition of HTO and does not consider reemission, a $0.0 \mathrm{~cm} / \mathrm{s}$ effective deposition velocity is recommended for safety analysis at SRS. Attempts made to adjust the particle re-suspension model in MACCS2 to account for HTO re-emission were unsuccessful due to the models inability to converge when using a re-suspension coefficient appropriate for $\mathrm{HTO}(>0.001)$. 


\section{TABLE OF CONTENTS}

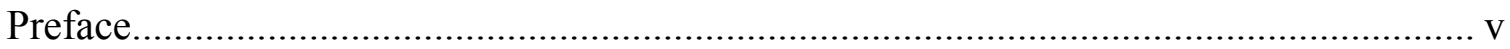

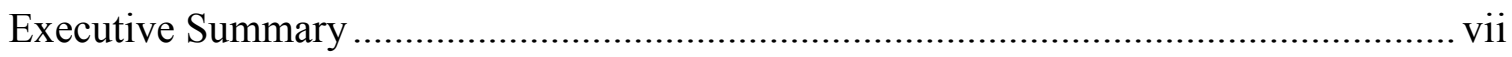

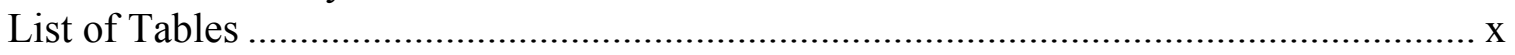

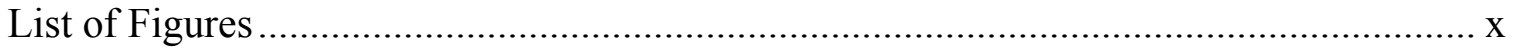

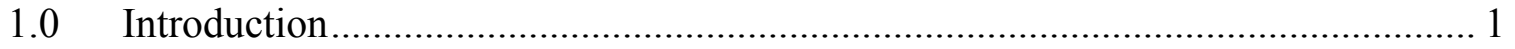

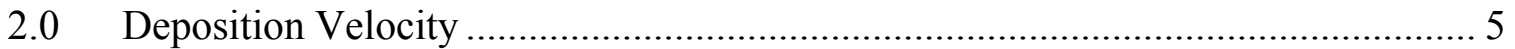

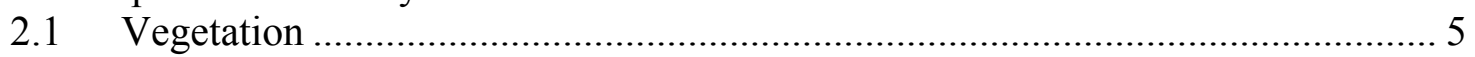

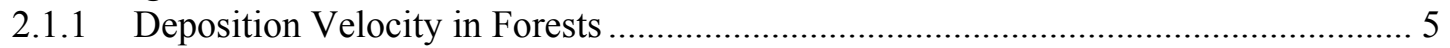

2.1.2 Calculation of Deposition Velocity in an SRS Pine Plantation ................................... 6

2.1.3 Calculation of Deposition Velocity for SRS Forests Considering Hardwood Stands. 7

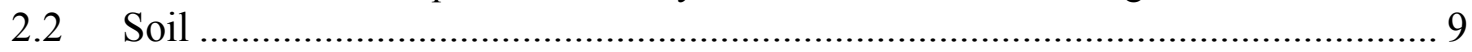

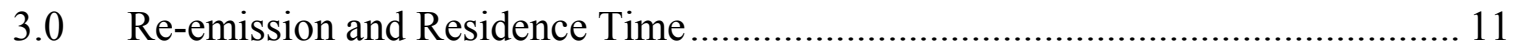

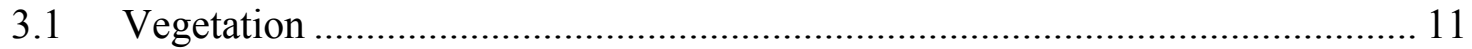

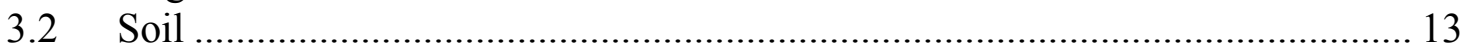

3.3 Combined Effects with Deposition Velocity ................................................... 14

4.0 Demonstrated Effects of HTO Deposition Velocity and Re-Emission at SRS .... 15

4.1 Deposition Velocity and Re-Emission Model................................................ 15

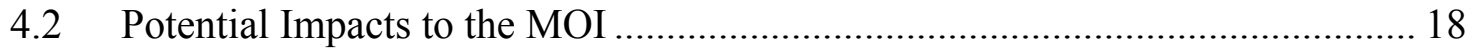

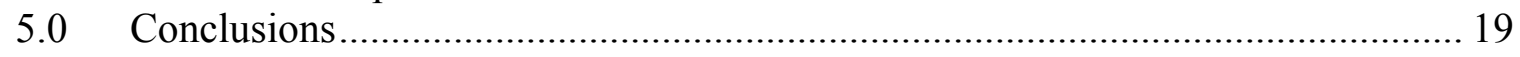

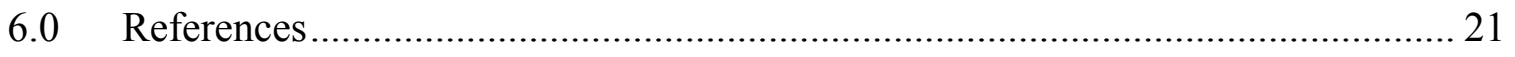




\section{LIST OF TABLES}

Table 1. Published measurements of leaf conductance for forest vegetation and the estimated stand deposition velocity 5

Table 2. Published measurements of forest deposition velocities ............................... 6

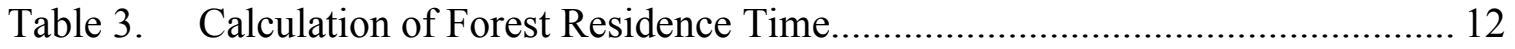

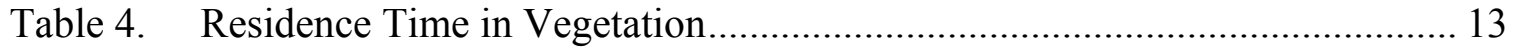

Table 5. Residence times for HTO in forest soils.................................................... 14

Table 6. The percent of a puff release of HTO that passes the site boundary $(\sim 11.5 \mathrm{~km})$ within 2 hours of first reaching it.

Table 7. The percent of a puff release of HTO at 100 meters downwind of the release point within 2 hours of first reach that distance................................................ 18

\section{LIST OF FIGURES}

Figure 1. The network of resistances to HTO vapor transport in a forest.

Figure 2. The frequency distribution of deposition velocity predicted for 15-min meteorology over a year.

Figure 3. Mean deposition velocity of SRS pine forest for Pasquill-Gifford stability classes.

Figure 4. A cross-section along the center-line of the HTO cloud two hours after first reaching the site boundary (labeled; $\sim 11.5 \mathrm{~km}$ ). 


\subsection{INTRODUCTION}

The DNFSB has recently questioned the basis for a Savannah River Site (SRS)-specific value for tritium deposition velocity of 0.5 centimeter per second $(\mathrm{cm} / \mathrm{s})$ currently used in the MELCOR Accident Consequence Code System Ver. 2 (MACCS2) (Chanin and Young 1998) dosimetry code when estimating bounding dose $\left(95^{\text {th }}\right.$ percentile) (DNFSB 2011). The purpose of this paper will be to provide appropriate, defensible values of the deposition velocity for use in SRS safety analyses.

Deposition velocity is defined as the proportionality constant relating air concentration to the flux density of material deposited under a puff or plume release. When dealing with large particles, the deposition velocity is dominated by the gravity-driven terminal velocity of the particles. Deposition of gases and vapors to the forest below a puff or plume is controlled by atmospheric diffusion and the absorption properties of the material on the surface of soil and vegetation.

In this document the deposition and cycling of HTO either as vapor in air or liquid in vegetation is addressed. It is assumed that the bounding condition in safety analysis is for tritium in the form of water. Other forms of tritium are either rare in the scenarios used for safety analysis or have lower dose consequences. Therefore, it is likely that if HTO releases are analyzed they will bound the upper safety consequences of actual, potential releases.

Deposition of HTO vapor is complicated by the relatively rapid re-emission of tritium from the surface once the plume passes. Most of the vapor diffusing into a stand of vegetation will dissolve in water in the leaves. A small fraction of the HTO vapor will reach the soil below the vegetation and dissolve in the soil water. Deposition will stop as equilibrium is reached between the concentration in the air and that in the leaf or soil water. After plume passage, the HTO will diffuse back as vapor into the atmosphere. The rate of diffusion back into the atmosphere is affected by the canopy temperature and the atmospheric pressure, as these factors affect the vapor pressure at the water surfaces within the canopy. The residence time, a measure of the relative re-emission rate of HTO, is shorter in the leaves of vegetation than in the soil where water can be sequestered in the system and have a longer residence time. The significance of re-emission will be evaluated as it is affected by residence time.

The deposition velocity estimates will be developed for SRS vegetation and climate. The SRS consists of 310 square miles of land in the piedmont and coastal plain of South Carolina. The US Forest Service manages $85 \%$ of the land area under an interagency agreement with the US Department of Energy (DOE). The remaining 15\% of the area is roads or production and administrative areas. The forested area is $68 \%$ pine plantations, $6 \%$ is mixed hardwood and pine forest, and $26 \%$ hardwood forest, predominately cypress/tupelo swamp forest.

Meteorological data used in the analyses, consisting of air temperature, relative humidity, and solar radiation, comes from a continuous record of quality assured 15-minute data 
collected at the SRS Central Climatology tower near N-area during 2010. This facility is located in an open grass-covered field to ensure the measurements are representative of ambient conditions. The temperature and relative humidity sensors are mounted at a height of 2-meters above ground. Solar radiation is measured nearby at ground level.

In the following sections a look is taken at the deposition velocity of water to forests, the residence time of HTO in forests, and the relation between deposition velocity and residence time. Where ever possible published experimental data are used in the analysis. Where this is not possible a simple resistance model, illustrated in Figure 1, is used to obtain values of deposition velocity and residence time of HTO in forests (Sinclair et al. 1976).

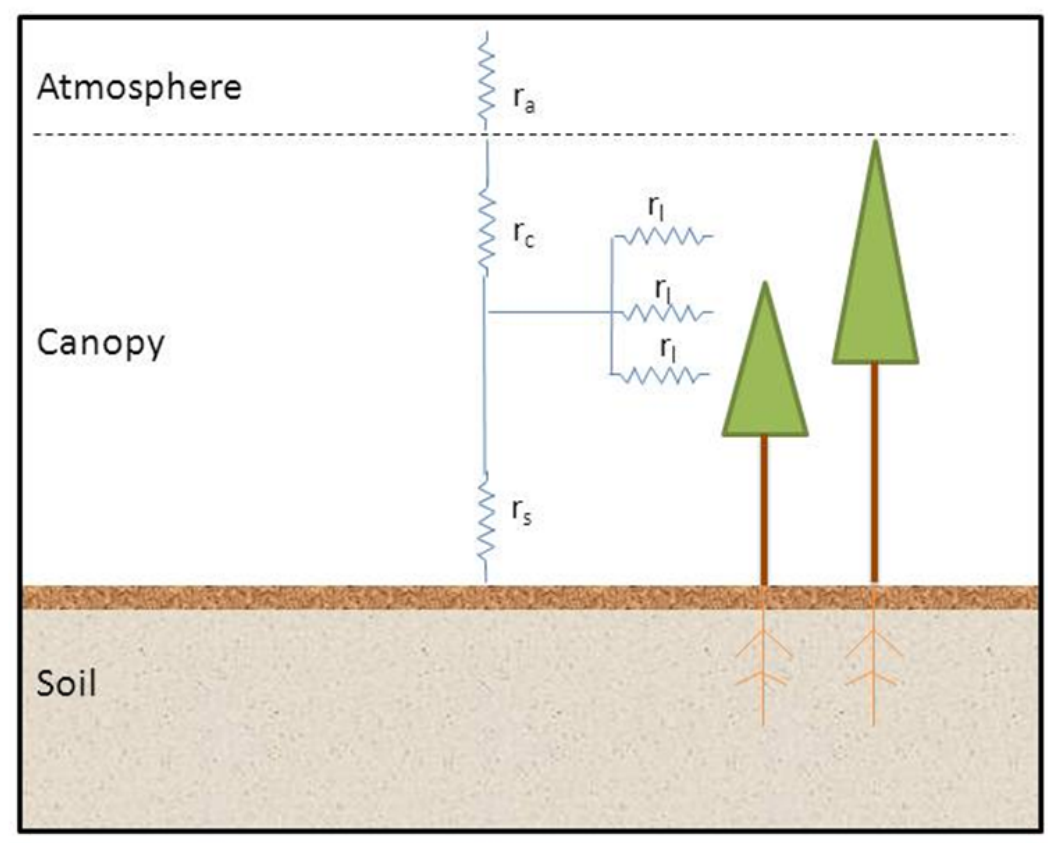

Figure 1. The network of resistances to HTO vapor transport in a forest.

Most of the time the soil transport is much smaller than that from the vegetation and can be ignored in calculating deposition velocity. In this case the deposition velocity can be evaluated by the equation.

$$
\mathrm{v}_{\mathrm{d}}=1 /\left(\mathrm{r}_{\mathrm{a}}+\mathrm{r}_{\mathrm{c}}+\mathrm{r}_{1} / \mathrm{LAI}\right)=1 /\left(\mathrm{r}_{\mathrm{a}}+\mathrm{r}_{\mathrm{c}}+1 /\left(\mathrm{LAI}^{*} \mathrm{~g}_{\mathrm{l}}\right)\right)
$$

where,

$\mathrm{v}_{\mathrm{d}}$ is the deposition velocity $(\mathrm{cm} / \mathrm{s})$

$r_{a}$ is the resistance from atmospheric diffusion in the boundary layer above the forest $(\mathrm{s} / \mathrm{cm})$

$r_{c}$ is the resistance from diffusion in air in the canopy $(\mathrm{s} / \mathrm{cm})$

$\mathrm{r}_{1}$ is the resistance for diffusion into the individual leaves $(\mathrm{s} / \mathrm{cm})$

LAI is the leaf area index $\left(\mathrm{cm}^{2} / \mathrm{cm}^{2}\right)$

$\mathrm{g}_{1}$ is the leaf conductance, the inverse of $\mathrm{r}_{1}(\mathrm{~cm} / \mathrm{s})$ 
During the winter leafless period, the flux from the vegetation approaches zero and the deposition velocity in a hardwood stand is the inverse of the soil resistance. Conditions that might increase the deposition velocity, such as accumulation of snow or ponded water, are rare in SRS's warm climate and sandy, porous soils. 


\subsection{DEPOSITION VELOCITY}

\section{$2.1 \quad$ Vegetation}

\subsubsection{Deposition Velocity in Forests}

The deposition velocity of water for vegetated surfaces has been measured in several ways. Estimates have been made by measuring the vapor transport of water of the individual components of a stand of vegetation, primarily leaves and secondarily the soil beneath the vegetation. Deposition velocity has also been measured for whole stands using energy balance, eddy correlation, and sap flow methods.

Table 1 shows the range of leaf conductance measured for a variety of forest tree species. The conductance is measured in chambers by the rate of accumulation of water vapor in the chamber, or in the case of Murphy and Corey (1976) by accumulation of HTO in the vegetation. The measurements of Kelliher et al. (1995) are reported as the mean and standard deviation of the maximum conductance for a large number of studies. The other conductances shown are the range for forest species found at SRS. The range shown does not imply that the measurements were made under conditions that show the total range for a species but only the range for the environmental conditions under which the studies were done. For instance, many of the studies did not measure the conductance at night.

Table 1. Published measurements of leaf conductance for forest vegetation and the estimated stand deposition velocity

\begin{tabular}{|l|c|c|c|l|}
\hline \multicolumn{1}{|c|}{ Vegetation Type } & $\begin{array}{c}\text { Leaf } \\
\text { Conductance } \\
\text { (cm/s) }\end{array}$ & $\begin{array}{c}\text { Estimated } \\
\text { Leaf Area } \\
\text { Index }\end{array}$ & $\begin{array}{c}\text { Estimated } \\
\text { Stand } \\
\text { Deposition } \\
\text { Velocity (cm/s) }\end{array}$ & \multicolumn{1}{|c|}{ References } \\
\hline Conifer forest & $0.57 \pm 0.24$ & 6.7 & $3.8 \pm 1.6$ & Kelliher et al. (1995) \\
\hline Temperate deciduous forest & $0.46 \pm 0.17$ & 5.1 & $2.3 \pm 0.9$ & Kelliher et al. (1995) \\
\hline Slash pine & $0.027-0.22$ & 8.7 & $0.2-1.9$ & Murphy and Corey (1976) \\
\hline Bald cypress & $0.73-0.66$ & 6.7 & $2.5-4.4$ & McLeod et al. (1986) \\
\hline Tupelo & $0.17-0.66$ & 5.1 & $0.9-4.0$ & McLeod et al. (1986) \\
\hline Black willow & $0.97-4.4$ & 5.1 & $4.9-22.4$ & McLeod et al. (1986) \\
\hline Button bush & $0.28-0.93$ & 5.1 & $1.4-4.7$ & McLeod et al. (1986) \\
\hline
\end{tabular}

As illustrated in Figure 1, the leaf resistances in the canopy are in a parallel network, and a rough estimate of the deposition velocity for the forest of a particular species can be made by multiplying the leaf conductance by the leaf area index, the leaf area per unit ground area (Table 1). The deposition velocity estimated in this way does not include the contribution of turbulent diffusion through the canopy and the aerodynamic boundary layer above the forest. However, since the resistance associated with the leaf conductance is usually much greater than the resistance associated with the canopy and boundary layer, estimates of deposition velocity made on the basis of leaf conductance can be 
useful when other estimates are not available. The leaf area indices provided in Table 1 are the mean values for forest stands of each species as compiled by Scurlock et al. (2001).

Table 2 shows the range of deposition velocities found in experimental studies of forest stands. The values reported by Kelliher et al. (1995) are the maximum and standard deviation of maximum deposition velocity compiled for a number of experiments. The other deposition velocities are the ranges reported in the cited paper. The measurements were made by several methods. Many of the studies used the Bowen ratio approach where the measured net radiation less the measured heat flux to the ground is partitioned between convective heat transfer and latent heat transfer. In study of the SRS pine forest (Murphy et al. 1981, Murphy 1985), measurements of temperature and water vapor profiles were used to determine the ratio. In the other experiment in the pine forest (Ewers et al. 2001), sap flow measurements were used to determine evaporation. In the other four studies (Wharton et al. 2009, Baldocchi 1989, Baldocchi et al. 2004, Blanken et al. 1997), the net radiant energy less heat flux to the ground was partitioned using eddy correlation measurements of convective and latent heat. Measurement periods varied from daily averages (Baldocchi 1989, Ewers et al. 2001) to hour averages (Murphy et al. 1981, Murphy et al. 1985, Blanken et al. 1997).

Table 2. Published measurements of forest deposition velocities

\begin{tabular}{|l|c|l|}
\hline \multicolumn{1}{|c|}{ Vegetation Type } & \multicolumn{1}{|c|}{$\begin{array}{c}\text { Stand deposition } \\
\text { velocity (cm/s) }\end{array}$} & \multicolumn{1}{c|}{ References } \\
\hline Conifer forest & $2.12 \pm 0.71$ & Kelliher et al. (1995) \\
\hline Temperate deciduous forest & $2.07 \pm 0.65$ & Kelliher et al. (1995) \\
\hline Mixed deciduous forest & 0.22 & Baldocchi (1989) \\
\hline SRS pine plantations & $0.07-1.2$ & Murphy et al. (1981), Murphy (1985) \\
\hline Douglas-fir forest & $>1$ & Wharton et al. (2009) \\
\hline Pine plantation & $0.02-0.24$ & Ewers et al. (2001) \\
\hline Oak-grass savannah & $0.02-0.2$ & Baldocchi et al. (2004) \\
\hline Aspen-hazel forest & $0.0-2.8$ & Blanken et al. (1997) \\
\hline
\end{tabular}

The results summarized in the Table 1 and Table 2 indicate that deposition velocities approaching or exceeding $1.0 \mathrm{~cm} / \mathrm{s}$ are found in forest stand. As expected the deposition velocities estimated from the leaf conductance measurements are generally somewhat higher than those measured for entire forests.

\subsubsection{Calculation of Deposition Velocity in an SRS Pine Plantation}

While the meteorological conditions affect the value of deposition velocity, the dominant factor is the diffusion of water into or out of the leaves. The leaf surfaces are covered with a waxy coating to suppress evaporation. Small openings, stoma, in the leaf surface allow passage of gas between the atmosphere and the interior of the leaf. 
The distribution of deposition velocity in a pine forest at SRS has been estimated from a model of canopy deposition velocities based on energy balance measurement taken in that stand (Murphy 1985, Equation 14).

$$
\mathrm{v}_{\mathrm{d}}=\mathrm{v}_{\mathrm{dmin}}+\left(\mathrm{v}_{\mathrm{dmax}}-\mathrm{v}_{\mathrm{dmin}}\right)\left(0.01218 \mathrm{~T}+0.0111 \mathrm{~S}-0.04374 \mathrm{~d}_{\mathrm{v}}\right)
$$

where,

$\mathrm{v}_{\mathrm{dmin}}$ is the minimum deposition velocity $(\mathrm{cm} / \mathrm{s})$

$\mathrm{v}_{\mathrm{dmax}}$ is the maximum deposition velocity $(\mathrm{cm} / \mathrm{s})$

$\mathrm{T}$ is temperature $\left({ }^{\circ} \mathrm{C}\right)$

$\mathrm{S}$ is solar radiation $\left(\mathrm{W} \mathrm{m}^{-2}\right)$ and

$\mathrm{d}_{\mathrm{v}}$ vapor density deficit, the difference between saturation density and actual vapor density based on relative humidity $\left(\mathrm{g} \mathrm{m}^{-3}\right)$.

In Murphy (1985) Equation 2 was developed using regression analysis of the experimentally derived deposition velocity and the simultaneous measurements of air temperature, solar radiation and vapor density deficit. During the regression analysis the values of $\mathrm{v}_{\mathrm{d}}$ were normalized by setting $\mathrm{v}_{\mathrm{dmin}}$ and $\mathrm{v}_{\mathrm{dmax}}$ slightly below and slightly above the observed values. When Equation 2 is used to calculate the deposition velocity outside of the range of the original experiments, care must be taken to make sure the extrapolation does not predict unreasonable results. An example would be for night condition $(S=0)$ under a high vapor density deficit when the calculation might yield a negative deposition velocity.

In the calculation made in this report, the value of $v_{\mathrm{dmax}}$ was set as $1.2 \mathrm{~cm} / \mathrm{s}$ based on the maximum observed deposition velocity in the cited data for a pine plantation. It is rare for the calculated values to reach the maximum. The value of $\mathrm{v}_{\mathrm{dmin}}$ is more difficult to evaluate. The stand level measurements depend on measurement of either very small temperature and vapor gradients or small eddy fluxes. In either case the sensitivity of the measurement technique is limited at low deposition velocities. Studies done on individual pine leaves suggest that the minimum deposition velocity for whole stands is likely be less than $0.2 \mathrm{~cm} / \mathrm{s}$ (Table 1, line 3) Since the value taken from leaf experiments is likely to overestimate the minimum deposition velocity for the stand, a value of $0.1 \mathrm{~cm} / \mathrm{s}$ was used in the calculations made for the pine plantation.

\subsubsection{Calculation of Deposition Velocity for SRS Forests Considering Hardwood Stands}

A complicating factor in using the deposition velocities derived from a pine stand to estimate the deposition velocity for use at SRS is the existence of a significant number of deciduous hardwood stands at SRS. Approximately $26 \%$ of the forested land is in hardwood forests and another 6\% in mixed hardwood pine stands (Parresol 2004). A model of hardwood stand response comparable to the pine stand data does not exist. However it is certain that the hardwood stands contain fewer leaves during the winter months (there are evergreen hardwood species in these stands). A rough correction for the hardwood component of the forest at SRS was made based on the relative area in each 
type of forest. It was assumed that the leafless period extended from the beginning of November to the end of March. The available data suggest that deposition velocity is very low in these stands during the winter but probably similar to that in the pine forest during the summer (Baldocchi et al. 2004). The deposition velocity for a leafless stand was set to $0.05 \mathrm{~cm} / \mathrm{s}$.

The frequency of deposition velocities throughout a year are shown in Figure 2. The calculations were performed using a continuous record of quality assured 15-minute values (35,040 observations per year) of temperature, relative humidity, and solar radiation collected at the SRS Central Climatology tower near N-area during 2010. The temperature and humidity data were collected from instrumentation mounted at a height of 2-meters above ground. Solar radiation is measured nearby at ground level. During the night, which is half of the year, the deposition velocity is at its minimum value. The deposition velocity during daylight hours is spread over a wide range as it responds to diurnal and annual variation in temperature, vapor density and temperature.

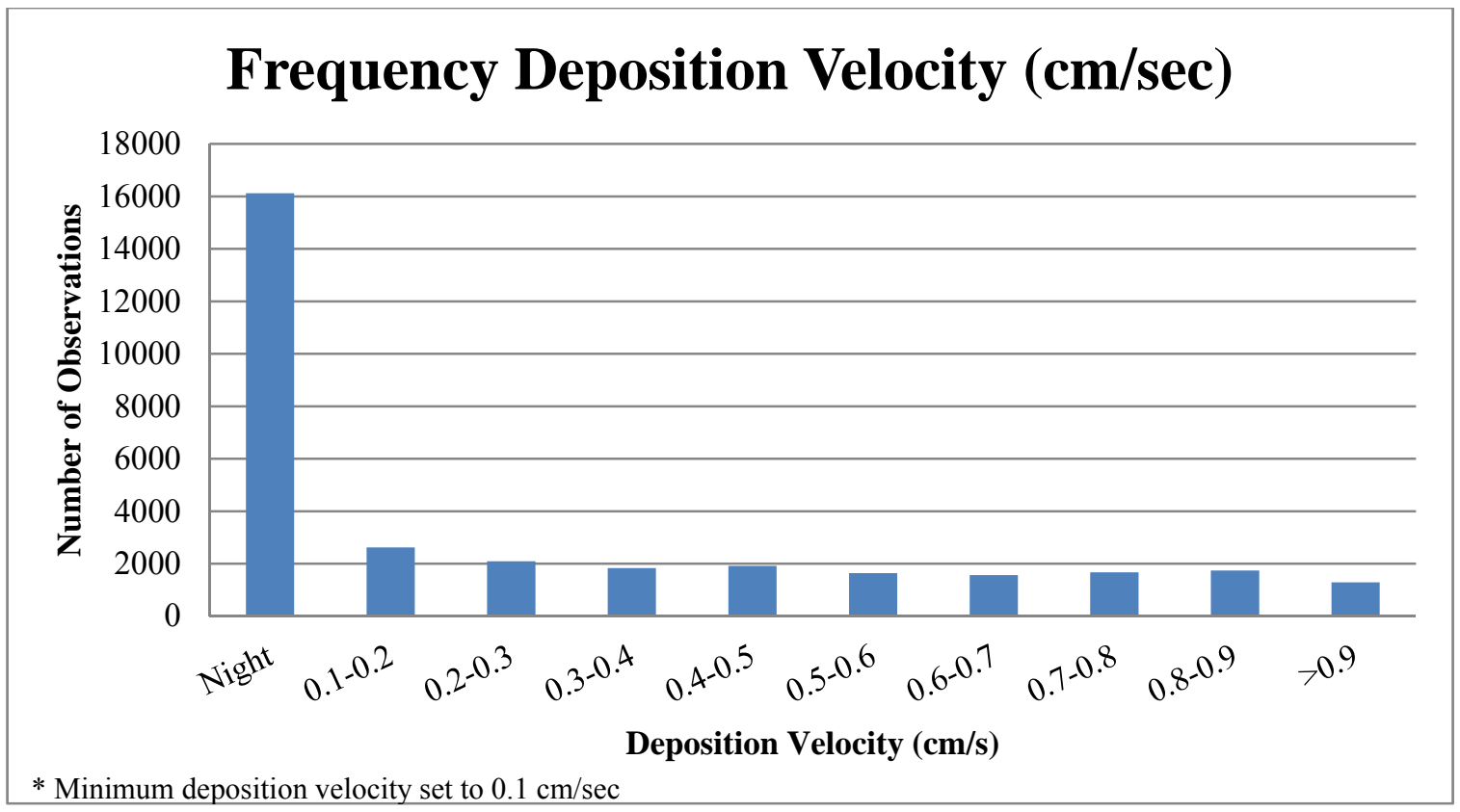

Figure 2. The frequency distribution of deposition velocity predicted for 15 -min meteorology over a year.

The average deposition velocity for the entire year is $0.27 \mathrm{~cm} / \mathrm{s}$. The average day time deposition velocity is $0.42 \mathrm{~cm} / \mathrm{s}$. The inclusion of the hardwood stands decreases the deposition velocities by $8 \%$. The relatively small influence of the loss of leaves by the hardwood stands is explained by the greater area in pine cover and the fact that half of the time the deposition velocity in both hardwood and pine stands is very low at night.

A better idea of how the deposition velocity in this forest is related to meteorological conditions affecting atmospheric dispersion is shown in Figure 3. The mean deposition velocity is plotted for the corresponding Pasquill-Gifford (PG) diffusion class over a 
single year. The determination of diffusion class was based on fifteen minute values of standard deviation in the vertical component of wind direction (sigma-elevation) following a method recommended by EPA (USEPA 2000). The sigma-elevation data were recorded at the 61-m level of the Central Climatology Tower.

It is clear that higher values of deposition velocity are associated with the PG stability classes that occur during sunny days (PG classes A and B) and the lower values are associated with stabilities that occur only at night (PG classes $\mathrm{E}$ and $\mathrm{F}$ ). The bars through the mean deposition velocity provide a measure of the range of deposition velocity around the mean for each stability class. The bars on the figure bracket $90 \%$ of the range of the calculated deposition velocities. Five percent of the values are equal to or less than the lower end of the bar and 5\% are equal to or greater than the upper end of the bar. It is clear that the lower bound of the D, E, and F stability class are determined by the lower bound set for the deposition velocity in Equation 2 and the lower boundary set for leafless hardwood forest. The co-incidental relationship between deposition velocity and stability class is significant with respect to the conditions that produce a $95^{\text {th }}$ percent dose for the maximally exposed offsite individual (MOI).

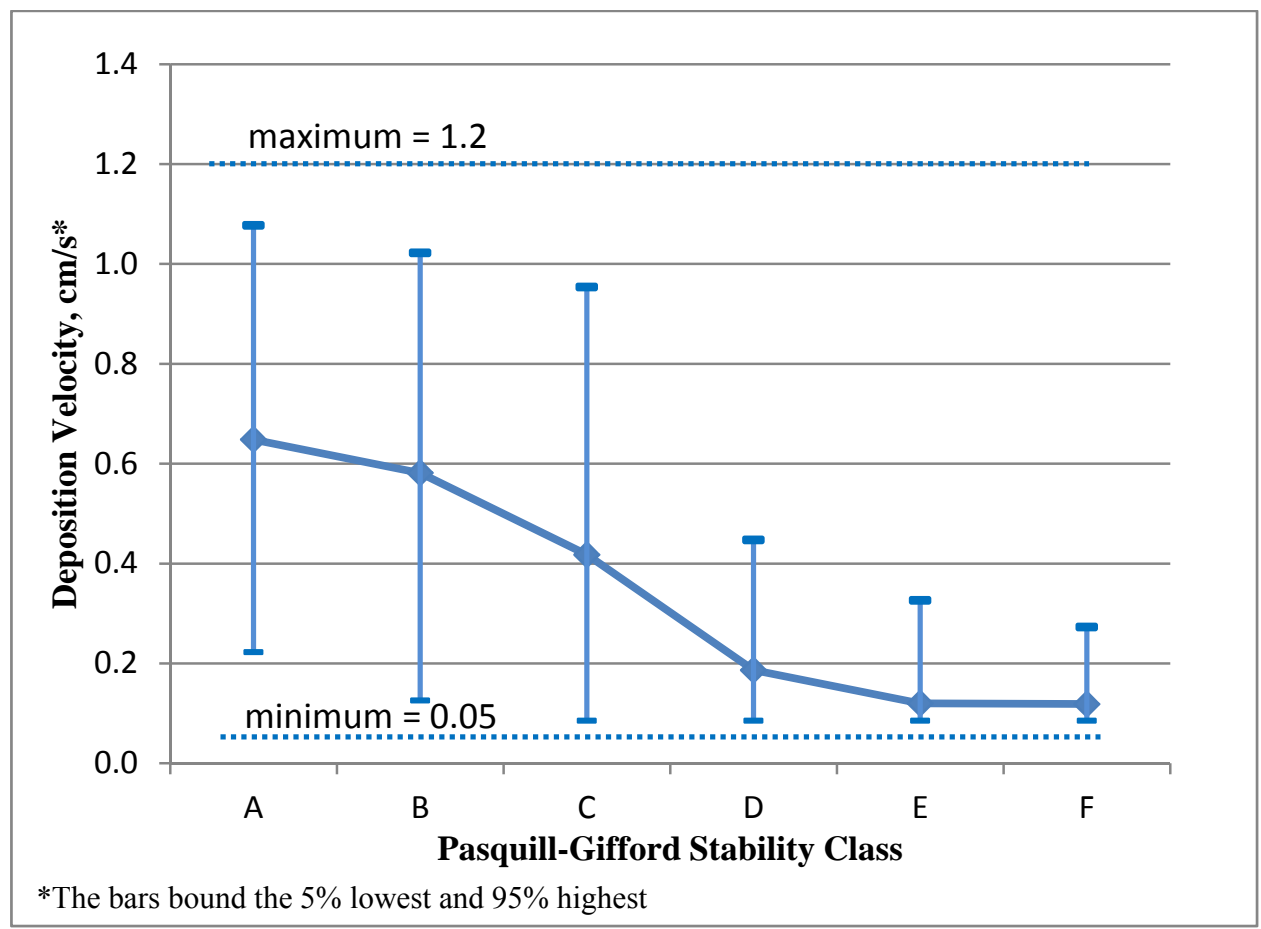

Figure 3. Mean deposition velocity of SRS pine forest for Pasquill-Gifford stability classes.

\subsection{Soil}

Water exchange between the atmosphere and soil in forests is expected to be much less than that between the atmosphere and the vegetation. This is based on consideration of two factors. The leaf surface area can be up to 10 times more per unit of ground surface 
area and the forest soil is covered (mulched) by a layer of litter derived from leaves and branches falling from the forest canopy. Measurements are not available for SRS soils. The best available estimate of soil deposition velocity in a forest is the deposition velocity for a leafless forest, probably less than $0.05 \mathrm{~cm} / \mathrm{s}$ (Baldocchi et al. 2004). This estimate might not apply to other vegetation types where different vegetation height and soil litter cover influence the exchange between the soil and the atmosphere. 


\subsection{RE-EMISSION AND RESIDENCE TIME}

\subsection{Vegetation}

The evaluation of the effects of HTO vapor deposition is complicated by the re-emission of tritium from the surface. Most of the HTO vapor diffusing into a stand of vegetation will dissolve in water in the leaves. Deposition will stop as equilibrium is reached between the concentration in the air and the concentration in the leaf. After plume passage, the HTO will diffuse back as vapor into the atmosphere. Assuming a constant wind direction as in MACCS2, this means that an MOI will be exposed to the re-emitted HTO vapor after exposure to the initial release. The total exposure will vary with the relationship between the MOI exposure period and the timing of the release and reemitted HTO vapor.

Residence times and deposition velocities for vegetation are linked through the common diffusion pathways involved in both processes. The equations linking the diffusion of water, HTO, and the energy balance of the vegetation were developed by Belot et al. (1979) and later used by Murphy (1984) to explain the measured ratio of HTO in air, vegetation and soil following chronic tritium emissions from nuclear facilities. The residence time as defined by the equations is:

$$
\mathrm{t}_{1 / 2}=-\ln (0.5) \cdot\left(\mathrm{V} / \mathrm{A} \cdot \rho_{\mathrm{w}}\right) /_{\rho_{\mathrm{as}} \cdot \mathrm{R}_{\mathrm{H}} \cdot \mathrm{v}_{\mathrm{d}}}
$$

where,

$$
\begin{aligned}
& \mathrm{t}_{1 / 2}=\text { residence time }(\mathrm{sec}) \\
& \mathrm{V}=\text { volume of water in vegetation per unit ground area }\left(\mathrm{cm}^{3} / \mathrm{cm}^{2}\right) \\
& \mathrm{A}=\text { surface area of vegetation per unit ground area }\left(\mathrm{cm}^{2} / \mathrm{cm}^{2}\right) \\
& \rho_{\mathrm{w}}=\text { density of water }\left(\mathrm{g} / \mathrm{cm}^{3}\right) \\
& \rho_{\mathrm{as}}=\text { saturation vapor density at vegetation temperature }\left(\mathrm{g} / \mathrm{cm}^{3}\right) \\
& \mathrm{R}_{\mathrm{H}}=\text { relative humidity }(\text { fraction }) \\
& \mathrm{v}_{\mathrm{d}}=\text { deposition velocity }(\mathrm{cm} / \mathrm{s})
\end{aligned}
$$

The leaf temperature is driven by the canopy energy balance. The relative humidity of the air also has an effect on the relationship of deposition velocity and residence time. A key relationship described in this equation is that residence time is inversely related to deposition velocity. The faster HTO enters the vegetation the faster it will leave the vegetation and the shorter the residence time. Conversely, if residence time is long, uptake will be low.

Table 3 shows calculations of residence time for forests under two scenarios. The first is for summer, daylight conditions typical of an SRS pine plantation. The second scenario is for summer, night conditions which approximate those suggested as limiting conditions for maximum exposures following an HTO release at SRS. 
Table 3. Calculation of Forest Residence Time

\begin{tabular}{|l|c|c|}
\hline & Day & Night \\
\hline Surface Area $\left(\mathrm{cm}^{2} / \mathrm{cm}^{2}\right)$ & 6 & 6 \\
\hline Water Volume $\left(\mathrm{cm}^{3} / \mathrm{cm}^{2}\right)$ & 0.1 & 0.1 \\
\hline Relative Humidity $($ fraction$)$ & 0.5 & 1 \\
\hline Surface Temperature $\left({ }^{\circ} \mathrm{C}\right)$ & 30 & 15 \\
\hline water density $\left(\mathrm{g} / \mathrm{cm}^{3}\right)$ & 1 & 1 \\
\hline Saturation Vapor Density $\left(\mathrm{g} / \mathrm{m}^{3}\right)$ & 31.0 & 12.4 \\
\hline Deposition Velocity $(\mathrm{cm} / \mathrm{s})$ & 0.5 & 0.1 \\
\hline Residence Time $(\mathbf{m i n})$ & $\mathbf{2 5}$ & $\mathbf{1 5 5}$ \\
\hline
\end{tabular}

Few data are available to compare the results in Table 3 to experimentally determined residence times for forests. Re-emission residence times have been determined experimentally for a number of agricultural species. The results have been reviewed in Boyer et al. (2009). They are expressed as the sum of three exponential release terms. The first term of the equation accounts for $99 \%$ of the HTO re-emitted. It is associated with the shortest residence time and is assumed to be re-emission from the vegetation. The longer residence times of the other two terms are assumed to be associated with soil re-emission, either directly from the soil surface or through transpiration through the vegetation of water taken up from the soil. Table 4 shows the range of re-emission residence times for various types of agricultural vegetation (collected by Boyer et al. 2009) and forest (Murphy and Corey 1976). The daylight residence times are in general agreement with those calculated by Equation 3.

The residence time during the night time hours is much longer. However, night time deposition velocities are much lower, $0.1 \mathrm{~cm} / \mathrm{s}$ or less. Table 4 shows some values of night time residence time for a few crops (collected by Boyer et al. 2009) and one forest vegetation type (Murphy and Corey 1976). Under night time conditions the amount of HTO taken up by the vegetation is very small even though it may be held in the vegetation for the rest of the night. The night residence time for forest vegetation appears to be somewhat shorter than for agricultural crops but still much longer than for the forest during the daylight. The night residence time for forests is in general agreement with the calculated values in Table 4 . 
Table 4. $\quad$ Residence Time in Vegetation

\begin{tabular}{|c|c|c|}
\hline Species (day) & $\begin{array}{c}\text { Residence Time } \\
\text { (hr) }\end{array}$ & Reference \\
\hline Potato and grape & 0.50 & \multirow{2}{*}{ Guenot and Belot (1984) ${ }^{1}$} \\
\hline Grape & 0.50 & \\
\hline Cabbage & 0.88 & \multirow{2}{*}{ Brudenell et al. (1997) ${ }^{1}$} \\
\hline Lettuce & 0.88 & \\
\hline Alfalfa & 0.33 & Koranda and Martin (1971) \\
\hline Grass (stem) & 0.42 & \multirow{2}{*}{ Kline and Stewart (1974) } \\
\hline Grass (leaves) & 0.58 & \\
\hline Rice & 0.50 & Keum et al. $(2006)^{1}$ \\
\hline Lettuce & 0.53 & \multirow{3}{*}{ Iyengar etal. $(1981)^{1}$} \\
\hline Cabbage & 0.75 & \\
\hline Pepper & 0.77 & \\
\hline Pine (leaves) & 1 & Murphy and Corey (1976) \\
\hline \multicolumn{3}{|l|}{ Species (night) } \\
\hline Grass (leaves) & 36.33 & Kline and Stewart (1974) ${ }^{1}$ \\
\hline Grass (stem) & 6.67 & \multirow{2}{*}{ Brudenell et al. $(1997)^{1}$} \\
\hline Lettuce & 13.00 & \\
\hline Pine (leaves) & 3 & Murphy and Corey (1976) \\
\hline
\end{tabular}

${ }^{1}$ Adapted from Boyer et al. (2009)

\subsection{Soil}

Residence times in forest soils are expected to be longer than those for vegetation, based on the lower deposition velocities and the greater potential water content of the soil. A few residence times are available from accidental and experimental exposures of soils. The second and third residence times calculated in the studies reported by Boyer et al. (2006) amount to $1 \%$ or less of the remitted HTO and are assumed to be directly from the soil surface or indirectly by root uptake and transpiration. They are summarized in Table 5. 
Table 5. $\quad$ Residence times for HTO in forest soils.

\begin{tabular}{|c|c|c|c|}
\hline \multirow[b]{2}{*}{ Species } & \multicolumn{2}{|c|}{ Residence Time (hr) } & \multirow[b]{2}{*}{ Reference } \\
\hline & Second & Third & \\
\hline Potato & 30 & & \multirow{2}{*}{ Guenot and Belot (1984) ${ }^{1}$} \\
\hline Grape & 30 & & \\
\hline Cabbage & 15 & 48 & \multirow{2}{*}{ Brudenell et al. (1997) ${ }^{1}$} \\
\hline Lettuce & 6 & & \\
\hline Alfalfa & 1 & 270 & Koranda and Martin (1971) ${ }^{1}$ \\
\hline Mixed Tropical & 60 & 1008 & Martin et al. (1970) \\
\hline Pine & 12.96 & 31.68 & Sweet et al. (1983) \\
\hline
\end{tabular}

${ }^{1}$ Adapted from Boyer et al. (2009)

The long residence time suggest that soil deposition could have a significant effect on the timing of exposures from atmospheric releases. However, the low deposition velocities associated with long residence times, $1 \%$ or less of the re-emitted HTO in the experiments described by Boyer et al. (2009), suggest that the amount of HTO reaching the soil is small compared to the vegetation. This suggests that deposition to the soil is not an important factor when estimating deposition velocity for short term accidental releases.

\subsection{Combined Effects with Deposition Velocity}

The evaluation of deposition velocity (Section 2.0), residence times and re-emission (Section 3.1) demonstrates that any reduction in exposure due to deposition of tritium will likely be eliminated by low initial uptake and subsequent re-emission back into the atmosphere (night) or rapid re-emission (day). For a bounding accident scenario at SRS, these factors lead to an "effective" deposit velocity of $0.0 \mathrm{~cm} / \mathrm{s}$ for HTO as demonstrated in Section 4.0. 


\subsection{DEMONSTRATED EFFECTS OF HTO DEPOSITION VELOCITY AND RE-EMISSION AT SRS}

In the previous sections the range of deposition velocities expected at SRS has been estimated. The deposition velocity is evaluated for different environmental conditions, which allows deposition velocity to be estimated for meteorological conditions which typically result in $95^{\text {th }}$ percentile MOI exposure. With this information, the effect and sensitivity of re-emission can be evaluated for releases of HTO over SRS forests.

Attempts made to adjust the particle re-suspension model in MACCS2 to account for HTO re-emission were unsuccessful due to the models inability to converge when using a re-suspension coefficient appropriate for HTO $(>0.001)$. As such, a simple model of the atmospheric dispersion, deposition, and re-emission was created to simulate the interaction between these processes (Viner 2012). The primary purpose of this simple model is to provide guidance regarding the effects of re-emission rather than for use as a predictor of potential consequences to an MOI. This model differs from typical models (i.e. MACCS2) in that it simulates a puff release resulting in a more concentrated cloud.

\subsection{Deposition Velocity and Re-Emission Model}

This simple model uses a series of grid cells that represent surface concentrations within the area encompassed by the cell. Spacing between the grid cells is $300 \mathrm{~m}$. The release is modeled as a single Gaussian puff that moves over the grid cells following the mean wind. Diffusion of the puff as it moves downwind is defined according to analytical expression defined by the EPA methods (USEPA 1995) for determining $\sigma_{y}$ and $\sigma_{z}$ for any input stability class. Diffusion in the along wind direction was based on setting $\sigma_{\mathrm{x}}$ equal to $\sigma_{\mathrm{y}}$. The analytical functions are based on fitting the Pasquill-Gifford diffusion curves.

At each time step within the model, deposition to the grid cell under a puff is calculated as:

where,

$$
\mathrm{D}=A * \mathrm{C}_{\mathrm{a} 0} * \mathrm{v}_{\mathrm{d}} * \Delta \mathrm{t}
$$

$\mathrm{D}=$ amount of HTO deposited (Ci)

$A=$ surface area of the ground $\left(\mathrm{m}^{2}\right)$

$\mathrm{C}_{\mathrm{a} 0}=$ atmospheric concentration of $\mathrm{HTO}\left(\mathrm{Ci} / \mathrm{m}^{3}\right)$

$\mathrm{v}_{\mathrm{d}}=$ deposition velocity $(\mathrm{m} / \mathrm{s})$

$\Delta \mathrm{t}=$ the model timestep (s)

The prediction of re-emission from a grid cell is performed similarly to the prediction of deposition, using a residence time constant which incorporates the characteristics of the SRS forest

$$
\mathrm{R}=\mathrm{V} * \mathrm{C}_{\mathrm{s}} *\left(1-\mathrm{e}^{-\Delta \mathrm{t} / \tau}\right)
$$

where 
$\mathrm{R}=$ the amount of HTO re-emitted from the grid cell $(\mathrm{Ci})$

$\mathrm{V}=$ the volume of plant material re-emitting $\mathrm{HTO}\left(\mathrm{m}^{3}\right)$

$\mathrm{C}_{\mathrm{s}}=$ the initial surface concentration in the grid cell $\left(\mathrm{Ci} / \mathrm{m}^{3}\right)$

$\Delta \mathrm{t}=$ the model timestep $(\mathrm{s})$

$\tau=$ the residence time constant $(\mathrm{s})$

The volume of plant material was assumed to be uniform across a grid cell with an effective depth of $1 \mathrm{~m}$, resulting in a volume equal to the area of a grid cell. The deposition and re-emission procedures are applied to each grid cell within the model.

Under the conditions imposed by this calculation, there will be a net increase in HTO concentration of the grid cell if deposition is greater than surface re-emission, no net transfer if the deposition is equal to the re-emission, and net a decrease in surface grid cell concentration if deposition is less than the re-emission. The atmospheric concentration of HTO at any time over a grid cell is calculated using a mass-balance equation of:

$$
\mathrm{C}_{a}=\left(\mathrm{HTO}+\Delta \mathrm{HTO}_{\mathrm{a}}+\mathrm{R}-\mathrm{D}\right) / \mathrm{V}_{\mathrm{g}}
$$

where

$\mathrm{HTO}=$ the initial amount of HTO over the grid cell $(\mathrm{Ci})$

$\Delta \mathrm{HTO}_{\mathrm{a}}=$ the net change in HTO over the grid cell due to advection $(\mathrm{Ci})$

$\mathrm{R}=$ the re-emitted tritium entering the atmosphere from the surface $(\mathrm{Ci})$

$\mathrm{D}=$ the deposited HTO leaving the atmosphere $(\mathrm{Ci})$

$\mathrm{V}_{\mathrm{g}}$ is the volume of air above the grid cell $\left(\mathrm{m}^{3}\right)$.

When HTO is re-emitted from the surface, an additional puff is created over the grid cell that released the HTO which is then dispersed downwind. When any puff exceeds the size of a grid cell, additional puffs are created in adjacent cells to represent the horizontal and vertical diffusion of HTO. Checks are performed within the model to ensure the sum of all HTO stored in puffs and at the surface equal the initial release.

The results of these calculations are shown in Figure 4 for meteorological conditions estimated to be typical of $95^{\text {th }}$ percentile exposure to an MOI at the SRS boundary (night time, $\mathrm{v}_{\mathrm{d}}=0.1 \mathrm{~cm} / \mathrm{s}, \tau=2.5 \mathrm{hr}, \mathrm{PG}$ Stability Class $\mathrm{F}$, wind speed $=100 \mathrm{~cm} / \mathrm{s}$ ). The figure illustrates the position of the puff $5.25 \mathrm{hr}$ after release, which corresponds to two hours after the plume originally reached the SRS boundary. At this time, $99.83 \%$ of the release has passed the MOI. 


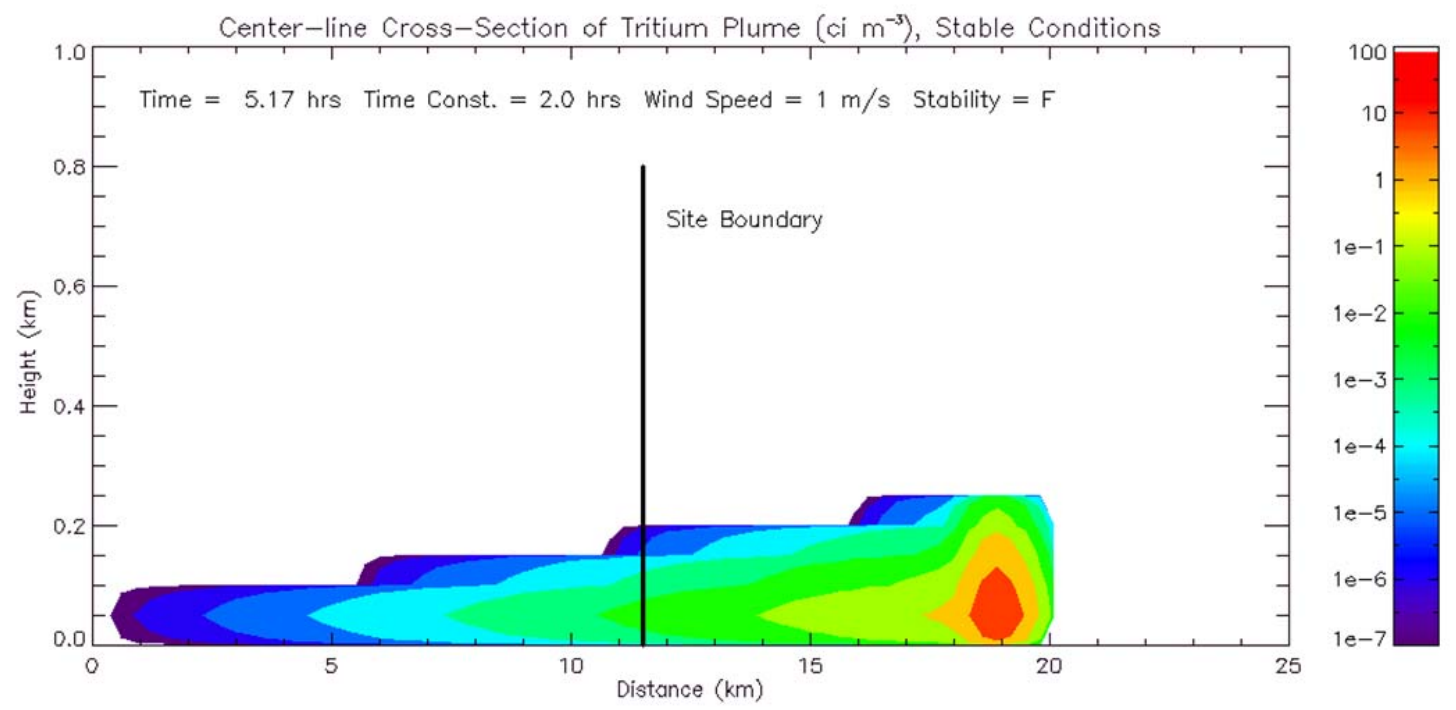

Figure 4. A cross-section along the center-line of the HTO cloud two hours after first reaching the site boundary (labeled; $\sim 11.5 \mathrm{~km}$ )

Note: The magnitude of concentration decreases rapidly behind the initial puff which is located at the right. The wind is blowing from left to right in this figure.

Table 6 shows the percent of the release impacting the MOI at the plant boundary for three release scenarios with varying deposition velocity: $0.0 \mathrm{~cm} / \mathrm{s}$ (no deposition; $\tau=\infty$ ), $0.1 \mathrm{~cm} / \mathrm{s}$ (estimated bounding value for MOI exposure; $\tau=2.5 \mathrm{hr})$ and $0.5 \mathrm{~cm} / \mathrm{s}(\tau=0.4$ $\mathrm{hr}$ ). The residence times used in the calculations for each deposition velocity correspond to those predicted by Equation 3. The MOI exposure with deposition considered is reduced by as much as $29.1 \%$ when re-emission is not taken into account. The maximum reduction in $2-\mathrm{hr}$ exposure is only $0.3 \%$ when re-emission is calculated. Note that in the 24-hr re-emission column, the values for 0.1 and $0.5 \mathrm{~cm} / \mathrm{s}$ are not theoretically equal to $100 \%$ since a very small amount of HTO will remain in the vegetation for an infinite amount of time. However, this amount is many orders of magnitude less than the original release and is considered negligible. These values are expected to be conservative for a plume release since the model used here simulates a puff.

Table 6. The percent of a puff release of HTO that passes the site boundary $(\sim 11.5 \mathrm{~km})$ within 2 hours of first reaching it

\begin{tabular}{|c|c|c|c|}
\hline \multirow{2}{*}{ Deposition Velocity (cm/s) } & \multirow{2}{*}{ No Re-emission } & \multicolumn{2}{|c|}{ With Re-emission } \\
\cline { 3 - 4 } & $100.00 \%$ & $100.00 \%$ & 24-hr \\
\hline 0.0 & $93.33 \%$ & $99.96 \%$ & $100.00 \%$ \\
\hline 0.1 & $70.89 \%$ & $99.70 \%$ & $100.00 \%$ \\
\hline 0.5 & \multicolumn{2}{|c|}{$\%$} & $100.00 \%$ \\
\hline
\end{tabular}

Table 7 shows the same scenarios as Table 6 but calculated at a distance of 100 meters from the release point using a grid spacing of $20 \mathrm{~m}$ and time step of $10 \mathrm{~s}$. The effect of deposition velocity on the calculation is extremely small. 
Table 7. The percent of a puff release of HTO at $\mathbf{1 0 0}$ meters downwind of the release point within 2 hours of first reach that distance.

\begin{tabular}{|c|c|c|}
\hline Deposition Velocity & No Re-emission & With Re-emission \\
\hline $\mathbf{0 . 0}$ & 100 & 100 \\
\hline $\mathbf{0 . 1}$ & $99.94 \%$ & $99.95 \%$ \\
\hline $\mathbf{0 . 5}$ & $99.70 \%$ & $99.99 \%$ \\
\hline
\end{tabular}

\subsection{Potential Impacts to the MOI}

The DNFSB letter not only questions the local, scientifically justifiable value of deposition velocity at SRS but also the dose to the MOI using this value in the MACCS2 code. The effect of using the $0.0 \mathrm{~cm} / \mathrm{s}$ deposition velocity recommended here rather than the default $0.5 \mathrm{~cm} / \mathrm{s}$ historically used in MACCS2 at SRS increases the dose to the MOI at the site boundary $(11.5 \mathrm{~km}$ ) by $17 \%$ (Hope 2012). Likewise, the effect of using a 0.1 $\mathrm{cm} / \mathrm{s}$ deposition velocity increases that dose only by $13 \%$. Because MACCS2 does not model re-emission, it is more appropriate to use the effective deposition velocity of 0.0 $\mathrm{cm} / \mathrm{s}$. As noted previously, MACCS2 simulates a continuous release resulting in plume dispersion whereas the modeling performed for this report treats the release as a puff. Because puff models are not as complex as plume models, they would yield a somewhat exaggerated difference in the MOI exposure with and without deposition.

The effect of the dose at 100 meter downwind is expected to be small since the plume has not passed over much forest. Actually, the area near the release point is a paved parking lot and deposition to the forest is not even possible. As expected, the effect of the value of deposition velocity used in the code is very small, an increase of dose of $1 \%$ when the $0.0 \mathrm{~cm} / \mathrm{s}$ deposition velocity is used rather than the $0.5 \mathrm{~cm} / \mathrm{s}$ historically used in MACCS2 at SRS (Hope 2012). 


\subsection{CONCLUSIONS}

Daylight HTO deposition velocities in forest vegetation can range from 0.07 to more than $2.8 \mathrm{~cm} / \mathrm{s}$. The average deposition velocity during daylight periods for an SRS pine plantation is around $0.42 \mathrm{~cm} / \mathrm{s}$. Night deposition velocities are much lower with the minimum deposition velocity likely to be around $0.1 \mathrm{~cm} / \mathrm{s}$.

Deposition velocity and residence time (half-life) of HTO are related by the leaf area and leaf water volume in the forest. For the characteristics of the pine plantation at SRS the daylight average residence time is about 0.4 hours and the night residence time is around 2.5 hours.

The simulations made with a simple puff model of atmospheric dispersion, deposition and re-emission of HTO vapor suggest that, for meteorological conditions defining the $95^{\text {th }}$ percentile maximum exposure (i.e. a $0.1 \mathrm{~cm} / \mathrm{s}$ deposition velocity), the net effect of deposition is very small because of the low initial deposition and the relatively rapid reemission of HTO during the 24-hour exposure time. Therefore, at SRS, it is recommended that an effective deposition velocity for HTO of $0.0 \mathrm{~cm} / \mathrm{s}$ is an appropriate bounding value for safety analysis with the MACCS2 code because the model does not specifically address HTO re-emission. 


\subsection{REFERENCES}

Baldocchi, D. D. 1989. Turbulent transfer in a deciduous forest, Tree Physiology 5: 357377.

Baldocchi, D. D., L. Xua and N. Kiang 2004. How plant functional-type, weather, seasonal drought, and soil physical properties alter water and energy fluxes of an oak-grass savanna and an annual grassland Agricultural and Forest Meteorology 123: 13-39.

Belot, Y., D. Gauthier, and H. Camus, and F. Bourdeau. 1979. Prediction of the flux of tritiated water from air to plant leaves. Health Physics 37:575-583.

Blanken, P. D., T. A. Black. P. C. Yang, H. H. Neumann, Z. Nesic, R. Staebler, G. den Hartog, M. D. Novak and X. Lee 1997. Energy balance and canopy conductance of a boreal aspen forest: Partitioning overstory and understory components. J. Geophysical Research 102 (D24): 28,915-28,927.

Boyer, C., L. Vichot, M. Fromm, Y. Losset, F. Tatin-Froux, P. Guetat, and P.M. Badot 2009 Tritum in plants: A review of current knowledge. Environmental and Experimental Botany 67:34-51.

Chanin, D. I. and M. L. Young 1998 Code Manual for MACCS2: Volume 1, User's Guide: NUREG/CR-6613/SAND97-0594, Sandia National Laboratories, U.S. Nuclear Regulatory Commission, Washington DC.

Defense Nuclear Facilities Safety Board (DNFSB) 2011. National Nuclear Security Administration, August 19, 2011. Letter, from Winokur to D’Agostino, Defense Nuclear Safety Board Safety Basis Development Issues with the Tritium Facilities at the Savannah River Site.

Ewers, B. E., R. Oren, N. Phillips, M. Stromgren and S. Linder 2001. Mean canopy stomatal conductance responses to water and nutrient availabilities in Picea abies and Pinus taeda. Tree Physiology 21: 841-850.

Hope, E. P. 2012, "Results for MACCS2 Assessment of Tritium Oxide Release" S-ESRG-00019 Revision 0.

Kelliher, F. M., R. Leuning, M. R. Raupach and E.-D. Schulze 1995. Maximum conductances for evaporation from global vegetation types. Agric. For. Meteorol. 73: $1-16$.

Martin, J. R., C. F. Jordan, J. J. Koranda, and J. R. Klaine 1970. Radiocological Studies of Tritium Movement in a Tropical Rain Forest, UCRL-72256, 20 pp. 
McLeod, K. W., L. A. Donovan, N. J. Stumpff, and K. C. Sherrod. 1986. Biomass, photosynthesis and water use efficiency of woody swamp species subjected to flooding and elevated water temperature. Tree Physiology 2:341-346.

Murphy, C. E. Jr. 1984. The relationship between tritiated water activities in air, vegetation, and soil under steady-state conditions. Health Physics 47:635-639.

Murphy, C. E. Jr. 1985. Carbon dioxide exchange and growth of a pine plantation. Forest Ecology and Management 11: 203-224.

Murphy, C. E. Jr. and J. C. Corey 1976. Absorption of HTO vapor from the atmosphere by the needles of pine trees. Eco. Soc. Amer. Special Publication 1, Radioecology and Energy Resources. Ed. C. Cushing. 108-112.

Murphy, C. E. Jr., J. R. Watts and J. C. Corey 1977. Environmental tritium transport from atmospheric releases of molecular tritium. Health Physics 33:3 25-331.

Murphy C. E. Jr., J. F. Schubert and A. H. Dexter 1981. The energy and mass exchange characteristics of a loblolly pine plantation. Journal of Applied Ecology 18: 271281.

Parresol, B. R. 2004. Point and Fixed Plot Sampling Inventory Estimates at the Savannah River Site, South Carolina, Report to the US Forest Service Savannah River February, 2004.

Scurlock, J. M. O., G. P. Asner, and S. T. Gower 2001. Worldwide Estimates of Leaf Area Index, 1932-2000. ORNL/TM-2001/268. Data set available at http://www.daac.ornl.gov. Oak Ridge National Laboratory Oak Ridge, Tennessee.

Sinclair, T. R., C. E. Murphy Jr, and K. R. Knoerr 1976. Development and evaluation of simplified models for simulating canopy photosynthesis and transpiration. Journal of Applied Ecology 13: 813-829.

Sweet, C. W., C. E. Murphy, and R. Lorenz 1983. Environmental tritium transport from and atmospheric release of HTO. Health Physics 44: 13-18.

U. S. Environmental Protection Agency (EPA) 1995. User's Guide for the Industrial Source Complex (ISC3) Dispersion Models. Volume II - Description of Model Algorithms, EPA-454/B-95-003b, Office of Air Quality Planning and Standards, Research Triangle Park, NC.

U. S. Environmental Protection Agency (EPA) 2000. Meteorological Monitoring Guidance for Regulatory Modeling Applications, EPA-454/R-99-005, Office of Air Quality Planning and Standards, Research Triangle Park, NC. 
Viner, B. J. 2012. Modeling Tritium Transport, Deposition and Re-emission, SRNL-STI2012-00131.

Wharton, S., M. Schroeder, K. Bible, M. Falk, T. P. U. Kyaw 2009. Stand-level gasexchange responses to seasonal drought in very young versus old Douglas-fir forests of the Pacific Northwest, USA. Tree Physiology 29: 959-974. 
Recommended HTO Deposition Velocity for Use in SRS Safety Analyses 


\section{Recommended HTO Deposition Velocity for Use in SRS Safety Analyses}

\section{$\underline{\text { Tritium Programs }}$}

Debra K. Utley

Donald W. Bickley

Marlene L. Moore

Chief Engineer, Tritium Programs

Deputy Chief Engineer, Tritium Programs

Tritium Engineering

\section{N\&CSE}

John C. Grove

Lawrence E. Johnson

Site Chief Engineer

Andrew M. Vincent

Manager, N\&CSE

Bonnie J. Shapiro

N\&CSE Safety Programs

Manager, N\&CSE SRNL and Tritium Support

Jon C. Guy

Eric P. Hope

N\&CSE SRNL and Tritium Support

N\&CSE Analytical Support

Scott K. Elliott

Manager, N\&CSE Analytical Support

$\underline{\text { NNSA }}$

Timothy M. Smith

AM for Mission Assurance

$\underline{\text { SRNL }}$

David E. Eyler

John E. Marra

Anthony E. Burris

Mary K. Harris

Alice M Murray

Lori M. Chandler

Stephen J. Hensel

Charles H. Hunter

John J. Mayer

Patricia L. Lee

G. Timothy Jannik

Charles E. Murphy

Brian J. Viner
Deputy Laboratory Director, SRNL Associate Laboratory Director, Science and Technology Associate Laboratory Director, National Security Director, Computational Sciences Acting Director, Environmental Sciences and Biotechnology Manager, Nonpoliferation Technology Manager, Computational Engineering and Sciences Manager, Atmospheric Technologies Manager, Environmental Sciences Manager, Applied Computational Engineering and Statistics Environmental Sciences Environmental Sciences Atmospheric Technologies 